\title{
RELATIONSHIP BETWEEN FINANCIAL RESOURCES AND HOME ENVIRONMENT AND STUDENTS' LEARNING RELATED ATTITUDES, BELIEFS AND BEHAVIORS
}

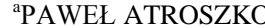

University of Gdańsk, Bażynskiego 1a, 80-952 Gdańsk, Poland email: ${ }^{a}$ p.atroszko@edu.gda.pl

Paper written within the frame of the research grant within the project of young scientists and PhD students of the University of Gdańsk in 2012. Title: Konstrukcja kwestion and zwiazku prom

fizycznego, psychicznego oraz satysfakcji z życia. Number: 538-7400-0890-12.

Abstract: Economic growth depends more and more on the potential of the society and economy to build and use knowledge. Fast and effectively learning people are needed. Two main problems were identified with the optimal usage of human capital as far as Two main problems were identified with the optimal usage of human capital as far as education is concerned: students who devote minimum effort and time to learning and acquiring qualifications, and students who learn compulsively, driven by dysfunctional perfectionism. This study tests relationship between financial resources and home

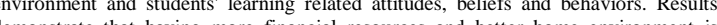
related to positive learning-related attitudes, beliefs and behaviors.

Keywords: learning, knowledge-based economy, financial resources, home environment, students, self-efficacy, perfectionism

\section{Introduction}

In recent years one can observe growing interest in analyzing social and economic problems from the perspective of knowledge-based economy (Piech, 2003). OECD (1996, p.7) defines knowledge-based economies as «economies which are directly based on the production, distribution and use of knowledge and information». Economic growth depends more and more on the potential of the society and economy to build and use knowledge. This, in turn, means that fast and effectively learning people are needed. From this perspective one of the greatest challenges for the development of the economy based on knowledge is an effective educational system. This requires understanding factors which determine effective and ineffective learning process.

Two main problems were identified with the optimal usage of human capital as far as education is concerned: students who devote minimum effort and time for learning and acquiring qualifications, and students who learn compulsively, driven by dysfunctional perfectionism (Atroszko, 2013). Those from the latter group are not only at high risk of developing full-blown syndrome of work addiction and its detrimental consequences for functioning, such as physical and psychological health problems, and disintegration of familial and social relationships, but also are most probably less productive than non compulsive engaged workers (Atroszko, 2013; for discussion on potential negative consequences of work addiction see: Atroszko, 2011).

Currently, more than ever before, there is need for appropriate understanding of factors conducive to acquiring knowledge and high competence, and those which determine negative attitudes towards learning and refrain development of human capital in the field of education. It is necessary to provide scientific knowledge about methods of encouriging positive learningrelated attitudes, beliefs and behaviours, such as high learning self-efficacy and high pleasure derived from learning, and prevent the negative ones, among which following can be identified: high learning compulsion and high learning-related dysfunctional perferctionism. What is more, negative learningrelated attitudes, beliefs and behaviours may include neglecting other domains of life, especially social relationships and health, and a tendency to getaway from personal problems into learning.

As far as educational possibilities are concerned, the existing research provides much data on the disadvantaged situation of those representing low socioeconomic status, especially in such countries as the United States of America (e.g. Orr, 2003; National Center for Education Statistics, 2008). These studies mainly concentrate on education of children (e.g. Aikens and Barbarin, 2008; Coley, 2002). They demonstrate that children from low socioeconomic households and communities develop academic skills slower compared to children from higher socioeconomic groups (Morgan, Farkas, Hillemeier, Maczuga, 2009).

However, there is scarce evidence of how adverse financial and home environment relates to particular attitudes, beliefs and behaviors among university students. One reason for the absence of systematic studies in this area might be that in many countries higher education requires paying fee and it limits students to the most motivated ones. Other reason may be that in pre-knowledge economy era there was less emphasis in the society and in the economy on knowledge, information and highly qualified and effectively learning employees. Recently, the widespread need for effective learners becomes increasingly pressing and becomes driving force for studies extending our understanding in this area.

On the basis of previous analyses of students learning related attitudes, beliefs and behaviors and their possible relationships with socioeconomic factors, following hypotheses were formulated:

1. The worse are financial resources and home environment the higher is compulsion to learn, learning-related dysfunctional perfectionism, learning overload, negligence of health and personal relationships, and tendency to get away from personal problems to learning.

2. The better are financial resources and home environment the higher is learning self-efficacy and pleasure derived from learning.

\section{Methods}

\subsection{Participants}

The study was a part of a large research project on the behaviours, attitudes and beliefs related to student learning, quality of life, stress levels, and coping with stress.

Thus far, 1,359 students of different fields of study, modes of study and years of study from the public and private universities in the Polish Tri-City area consisting of Gdańsk, Sopot, and Gdynia participated in the study. The data analysed in this article was gathered in the period from May 2012 to January 2013 outside the examination session and not directly before or after it (over three weeks). Among the subjects were students from first to fifth year of study. The study group included both full-time students and part-time students. Among the respondents were 844 (62.1\%) women and 515 men. The average age was 20.06 years $(\mathrm{SD}=2,70)$

At this point, it is important to note that one of the limitations of the study is slight over representation of women in the sample. This is due to the fact that at this stage - despite the initial assumption of the quota selection and effort to secure the appropriate balance between women and men, students from public and private universities, types of universities, mode of study, courses and years of study - the study sample is a convenience sample.

\subsection{Instruments}

Multidimensional Inventory - Learning Profile of a Student (MILPoS). One of the psychometric tools used in the study was original scale to assess the learning-related behaviors, attitudes, feelings and beliefs. The inventory consists of nine scales measuring learning compulsion, learning-related dysfunctional perfectionism, learning overload, negligence of health, negligence of personal relationships, tendency to getaway from personal problems to learning, learning self-efficacy, and pleasure derived from learning. The scale is intended as a 
measure of study addiction components and risk factors. It also includes the scale of the level of energetic arousal as a variable differentiating between hypomanic study addicts and burnout study addicts. Results on this scale were not presented in this article. Respondents provided answers on a five-point Likert scale, from 1 - very rarely to 5 - very often. Thus far, the data obtained showed adequate reliability and validity of this tool. Confirmatory factor analysis confirmed good fit of the measurement model of nine correlated components to data. Cronbach's alpha for particular subscales varied between .70 and .87 (Atroszko, 2013). Convergent and divergent validity of the scales was demonstrated. Compulsion, Perfectionism, Negligence of Social Relationships scales were correlated with Psychastenia scale from MMPI and Doubts about Actions, Concern over Mistakes and Personal Standards from Frost's Multidimensional Perfectionism Scale. MI-LPoS scales did not correlate with Parental Expectations and Parental Criticism scales from Multidimensional Perfectionism Scale, except for low positive correlations with learning-related dysfunctional perfectionism and low negative correlation between learning self-efficacy and Parental Criticism scale.

World Health Organization Quality of Life Scale (WHOQoLBref). The WHOQOL - Bref is a generic questionnaire based on a conceptualization of quality of life as an individuals' perception of their situation in life in the context of the culture and value systems in which they live and in relation to their goals, standards, expectations, and concerns (The WHOQOL Group, 1998). It consists of 26 items. WHOQOL - Bref measures quality of life in four domains: physical health, psychological, social relationships and environmental. Each domain consists of three to eight items. What is more, two overall questions yield information on global QoL (Q1), and satisfaction with general health (Q2). Self-report items are scored on a scale from one to five. Higher scores indicate higher QoL with the exception of three items which include pain and discomfort, need for medical treatment and negative feelings (The WHOQOL Group, 1998a). Participants are asked to response in reference to how they assess their life in previous two weeks. WHOQOL - Bref is available in 50 languages. Polish version has adequate reliability and validity. Cronbach's alpha for particular subscales varied between .69 and .84 . For the purpose of the analysis presented in this article two items measuring environmental domains were used: one asking about financial resources, that is, having enough money to meet persons needs and second about home environment, that is, satisfaction with the conditions of living place.

Demographic data. Data on gender, age, marital status, place of living, paid employment were gathered. In this article only relationship between gender and age with other study variables is discussed.

\subsection{Procedure}

Participation in the study was voluntary. Before completing questionnaires, subjects were informed that the survey is anonymous and the results will be used solely for the purposes of the research. Basic information about the study purposes was provided for the participants before completion of the questionnaires and their consent was obtained. Questionnaires were completed in a single session. After filling in the questionnaires participants could ask further questions about the study.

\subsection{Statistical analyses}

Descriptive statistics were calculated. Point-biserial correlation coefficients were obtained for the relationship between gender and other study variables, except for correlation between gender and financial resources and home environment for which rankbiserial coefficients were calculated. Women were coded as 0 and men coded as 1 . Spearman's rank correlation coefficient rho was used as a measure of association between financial resources and home environment measured on the ordinal level and learning related behaviors, attitudes, beliefs and feelings, as well as age measured on the numerical level. For the relationship among other study variables Pearson product-moment correlation coefficients were obtained. Statistical analyses were performed with IBM SPSS 20.PL software.

\section{Results}

Table 1 presents correlation coefficients between study variables. The results concerning relationship of gender with study variables indicate that being a women is related to higher compulsion to learn, $\mathrm{r}=-.10$, $\mathrm{p}<0.01$, higher learning-related dysfunctional perfectionism, $\mathrm{r}=-.17, \mathrm{p}<0.01$, higher learning overload, $\mathrm{r}=-.16, \mathrm{p}<0.01$, and higher tendency to getaway from personal problems to learning, $\mathrm{r}=-.17, \mathrm{p}<0.01$. At the same time being a women is related to lower learning selfefficacy, $\mathrm{r}=.12, \mathrm{p}<0.01$. There was no relationship between gender and pleasure derived from learning, negligence of health and personal relationships.

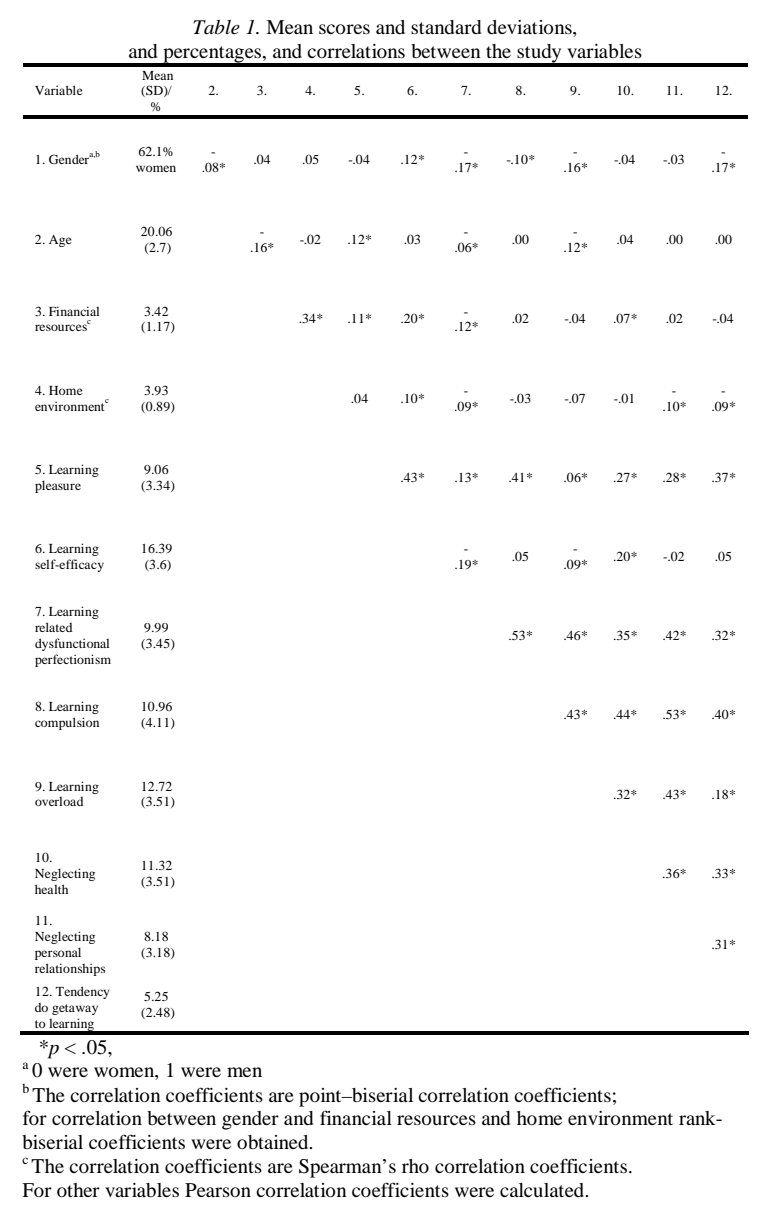

Age correlated negatively with financial resources, $\mathrm{r}=-.16, \mathrm{p}<$ 0.01 . The correlation was low and indicated that the older is a student the worse is his or her subjective evaluation of his or her financial resources. Age correlated positively with pleasure derived from learning, $\mathrm{r}=.12, \mathrm{p}<0.01$, and negatively with learning-related dysfunctional perfectionism $\mathrm{r}=.06, \mathrm{p}<0.05$, and learning overload, $\mathrm{r}=.12, \mathrm{p}<0.01$. The correlation coefficients were low and very low, however, they indicated slight tendency to more positive attitudes, beliefs and behaviours in older students in comparison to younger ones. There was no relationship between age and learning self-efficacy, compulsion to learn, negligence of health and personal relationships, tendency to getaway from personal problems to learning.

Pleasure derived from learning correlated positively with learning self-efficacy, $\mathrm{r}=.43, \mathrm{p}<0.01$, compulsion to learn, $\mathrm{r}=$ $.41, \mathrm{p}<0.01$ negligence of health, $\mathrm{r}=.28, \mathrm{p}<0.01$, negligence of personal relationships, $\mathrm{r}=.27, \mathrm{p}<0.01$ and tendency to getaway 
from personal problems to learning $r=.37$, $p<0.01$. Pleasure derived from learning manifested very low positive correlations also with learning-related dysfunctional perfectionism, $r=.13, \mathrm{p}$ $<0.01$, and learning overload, $r=.06, p<0.05$. These results suggest that addiction-related attitudes, beliefs and behaviours have stronger, as in the case of compulsion and negligence of health and relationships, or weaker, as in the case of perfectionism and overload, component of pleasure. This is consistent with addiction development models which assume that in the beginning there is pleasure derived from certain behaviours or substances, which later develops into compulsion.

Learning-related self-efficacy correlated negatively with dysfunctional perfectionism, $\mathrm{r}=-.19, \mathrm{p}<0.01$, and learning overload, $r=.09, \mathrm{p}<0.01$, and positively with negligence of health, $r=.20, p<0.01$. Positive relationship between learning self-efficacy and neglecting health problems requires more studies in order to assess how this relates to psychosocial functioning in short and long term.

All negative learning-related attitudes, beliefs and behaviours were correlated positively, with highest correlation between compulsion and perfectionism, $\mathrm{r}=.53, \mathrm{p}<0.01$ and compulsion and neglecting social relationships $r=.53, p<0.01$. The weakest observed relationship was between learning overload and tendency to getaway from personal problems to learning, $r=.18$, $\mathrm{p}<0.01$.

The most important results concerned the relationship between financial resources and home environment and learning related attitudes, beliefs and behaviours. There was positive correlation between financial resources and home environment, $\mathrm{rs}=.34, \mathrm{p}<$ 0.01 , which indicate that even though, as expected, these two indicators of material resources, and, as such, indicators of socioeconomic status, were related, the amount of non-shared variance between them was substantial (about 88\%). This suggests that different factors may influence the condition of students financial resources and home environment, and/or the way that students subjectively asses them.

Financial resources correlated pisitively with self-efficacy, rs = $.20, \mathrm{p}<0.01$, pleasure derived from learning, $\mathrm{rs}=.11, \mathrm{p}<0.01$, and slightly lower with negligence of health, $\mathrm{rs}=.07, \mathrm{p}<0.05$. Home environment correlated positively with self-efficacy rs $=$ $.10, \mathrm{p}<0.01$, and negatively with learning-related dysfunctional perfectionism, $\mathrm{rs}=-.09, \mathrm{p}<0.01$, learning overload, $\mathrm{rs}=-.07$, $\mathrm{p}$ $<0.05$, negligence of personal relationships, $r s=-.10, \mathrm{p}<0.01$, and tendency to getaway from personal problems to learning, rs $=-.09, \mathrm{p}<0.01$.

\section{Statistical analyses}

First, it has to be emphasized that most of the relationships between financial resources and home environment with learning-related attitudes, beliefs and behaviours were weak or very weak. Most of the correlation coefficients were statistically significant due to very large sample size. According to the interpretation standards for effect size (Cohen, 1988), the effect size for most of the tested relationships was small. However, the effect size has to be estimated and interpreted in the context of the research problem, especially when small effects are observed for phenomena related with very undesirable outcomes for human functioning which relate to great number of people (cf. Atroszko, Kowalczyk, Kowalczyk, 2013). This is because very weak relationships between variables which relate to populations of hundreds of thousands or millions translate to significant differences for thousands and tens of thousands of people. In the case of research concerning education the number of people affected by studied phenomena is huge, and in the context of knowledge-based economy it seems to encompass most of the society. For example, in Poland in 2010 there were almost two million students (GUS, 2011). In the case of such large population and in the context of studied education-related phenomena even small effect may relate to very meaningful outcomes, such as dropout rates, risk of psychological disorders and other health problems, not to mention costs in time and money spend on ineffective learning.

In the view of that, the positive relationships observed between financial resources and home environment and positive learningrelated attitudes, beliefs and behaviours and negative relationships between financial resources and home environment and negative learning-related attitudes, beliefs and behaviours are worth great attention. These results mostly confirmed the hypotheses.

The most salient result is that financial resources are related to higher learning self-efficacy. It is especially worth noting because learning self-efficacy is most probably directly related to educational outcomes. There are several plausible explanations of this relationship. One is that having financial resources allows you to spend them on educational materials such as books, software, etc. Having financial resources may allow you to spend more time on learning and less on earning the living. This is also directly related to the possibility that when you have financial resources you may also, on a cognitive level, concentrate more on learning and less on how to earn money for your basic needs. On the emotional level, having financial resources may allow you to derive more pleasure from learning, as you do not have to worry about your household necessities, and pleasure derived from learning is related to learning selfefficacy. On the other hand, having material resources and high learning self-efficacy might be explained, at least partly, by other variable such as general self-efficacy. People who are effective in dealing with different tasks and difficulties in their life may be able to ensure more resources for themselves and be more effective learners.

Both financial resources and home environment were negatively related to learning-related dysfunctional perfectionism. Studies suggest that dysfunctional-perfectionism may be the core determinant of work and study compulsion (Atroszko, 2010) which is the main component of work and study addiction. Detrimental effects of workaholism on all domains of functioning of a person are now recognized and necessity of early interventions is emphasized (cf. Atroszko, 2011). Dysfunctional perfectionism is the tendency to avoid any errors and concern over mistakes because the person beliefs that any fault, blunder and sign of incompetence may cause other people to dislike and/or disrespect them. It seems plausible that this belief may be stronger in persons in worse financial situation and home environment as lack of resources may cause them to be more vulnerable to the threat of social exclusion, and consequently further exclusion from access to resources. This is important not only from the perspective of the development of study or work addiction syndrome, but also because dysfunctional perfectionism is one of the most important psychological factors in the development of variety of behavior disorders and a risk factor for suicide (O’Connor, 2007).

Overall conclusion of this study is that having more financial resources and better home environment is related to positive learning-related attitudes, beliefs and behaviours. From the perspective of the development of knowledge-based economy it is necessary to understand all factors facilitating effective knowledge production, distribution, acquisition, processing and practical usage. Lack of financial resources may be directly related to worse educational possibilities due to inability to gain access to educational resources such as books, software, paid courses, tutors etc. However, growing development of open access educational resources in the internet shifts attention, especially in the developed countries, to psychological factors which may hinder effective learning in students who have access to all needed educational resources. Relatively disadvantaged financial and home environment situation may influence psychological processes which impede effective knowledge attainment in those who otherwise have access to all necessary information. Understanding these processes is crucial for optimizing development of knowledge-based economies. If worse financial situation causes higher learning-related dysfunctional perfectionism and this in turn causes less effective 
learning and higher stress, higher risk of depression and other psychological disorders, as well as physical symptoms, then it is crucial to understand what are the conditions preventing this process to occur. In other words what is the optimal resource distribution to optimize knowledge acquisition and knowledge economy development.

The strength of this study lays in a large and heterogenic group of students from different universities, different faculties, courses of study, modes of study and years of study. All instruments used in the study showed adequate reliability and validity.

A cross-sectional design in the present study was employed and thus conclusions about causes and effects cannot be drawn. All data in the study were based on self-report, therefore the results may have been influenced by the common method bias (Podsakoff, MacKenzie, Lee, Podsakoff, 2003). Future research should determine whether there is causal link between broadly understood socioeconomic status and negative learning-related attitudes, beliefs and behaviours, including learning time commitment, as it seems crucial in the light of the current studies demonstrating gradual decrease in average time that students devote to learning (cf. Babcock and Marks, 2010). Future studies should also take into account possible moderating effects of socioeconomic factors on the relationship between attitudes towards learning and learning time commitment.

\section{Literature:}

1. Aikens, N. L., Barbarin, O. Socioeconomic differences in reading trajectories: The contribution of family, neighborhood, and school contexts. Journal of Educational Psychology, 100, 2008, pp. 235-251. ISSN 0022-0663.

2. Atroszko, P. Uzależnienie od pracy - wynik ,słabej woli” czy potrzeba doskonałości. Studia Psychologica, 10, 2010, pp. 179-194. ISSN 1642-2473.

3. Atroszko, P. Uzależnienie od pracy jako zakłócenie równowagi między pracą a czasem wolnym, in: Praca, społeczeństwo, gospodarka. Między polityka a rynkiem, ed. J. Osiński, Oficyna Wydawnicza Szkoła Główna Handlowa w Warszawie, Warszawa, 2011, pp. 17-29. ISBN 9788373786578.

4. Atroszko, P. Uzależnienia od uczenia się - związek między czynnikami ryzyka, komponentami uzależnienia oraz depresyjnością. The Third International Postgraduate Conference Psychological Research Method Toolkit, Ciążeń, Poland, 20th April, 2013. Paper presented at the Conference.

5. Atroszko, P. Zachowania i postawy studentów związane z uczeniem się a determinanty rozwoju gospodarki opartej na wiedzy. Warszawa: Wydawnictwo SGH (in press).

6. Atroszko, P., Kowalczyk, J., Kowalczyk, W. Emotionrelated personality traits in hypertensive patients - pilot study. Nadciśnienie Tętnicze, 2013, 17, no 1, pp. 30-37. ISSN 1428-5851.

7. Babcock P., Marks M. Leisure College, USA: The Decline in Student Study Time, American Enterprise Institute for Public Policy Research, 2010, no. 7. ISSN 1047-3572.

8. Cohen, J. Statistical power analysis for the behavioral sciences. Second Edition. Hillsdale, NJ: Lawrence Erlbaum Associates, Publishers, 1988. ISBN 978-0805802832.

9. Coley, R. J. An uneven start: Indicators of inequality in school readiness. Princeton, NJ: Educational Testing Service, 2002. Retrieved from: http://www.ets.org/Media/Research/pdf/ PICUNEVENSTART.pdf

10. GUS, Szkoły wyższe i ich finanse w roku 2010, Warszawa 2011. ISSN 1506-2163.

11. Morgan, P. L., Farkas, G., Hillemeier, M. M., Maczuga, S. Risk factors for learning-related behavior problems at 24 months of age: Population-based estimates. Journal of Abnormal Child Psychology, 37, 2009, pp. 401-413. ISSN 0091-0627.

12. National Center For Education And Statistics. Percentage of high school dropouts among persons 16 through 24 years old (status dropout rate), by income level, and percentage distribution of status dropouts, by labor force status and educational attainment: 1970 through 2007. 2008. Retrieved from http://nces.ed.gov/programs/digest/d 08/tables/dt08_110.asp

13. OECD, The Knowledge-Based Economy, Paris 1996. p.7. Retrieved from: http://www.oecd.org/science/sci-tech/ 1913021.pdf

14. ORR, A. J. Black-White differences in achievement: The importance of wealth. Sociology of Education, 76. 2003, pp. 281-304. ISSN 0038-0407.

15. Piech, K. Gospodarka oparta na wiedzy w Polsce, in: Ekonomiczne instrumenty wsparcia ożywienia gospodarki w Polsce, red. K. Szczepaniak, K. Zbytniewska, Oficyna Wydawnicza SGH, Warszawa, 2003, pp. 263-271. ISBN 9788373780279.

16. Podsakoff, P.M., Mackenzie, S.M., Lee, J., Podsakoff, N.P. Common method variance in behavioral research: A critical review of the literature and recommended remedies. Journal of Applied Psychology, 88, 2003. pp. 879-903. ISSN 0021-9010.

17. O'Connor, R.C. The Relations between Perfectionism and Suicidality: A Systematic Review. Suicide and LifeThreatening Behavior, Vol. 37, No. 6, 2007, pp.698-714. ISSN 1943-278X

18. The WHOQOL Group. Development of the WHOQOL Bref quality of life assessment. Psychological Medicine, 28, 1998, pp. 551-558. ISSN 0033-2917.

19. The WHOQOL Group. The World Health Organization quality of life assessment (WHOQOL): development and general psychometric properties. Social Science and Medicine, 46, 1998a, pp. 1569-1585. ISSN 0037-7856.

\section{Primary Paper Section: A}

Secondary Paper Section: AM, AN 